\title{
55. A Dolerite Block Dredged from the Bottom of the Vitiaz Deep, Mariana Trench
}

\author{
By Kenzo YaGI \\ Institute of Earth Sciences, Tôhoku University, Sendai \\ (Comm. by S. Tsubor, M.J.A., April 12, 1960)
}

Introduction. Recently a dolerite block obtained from the Vitiaz deep was placed at the writer's disposal through the courtesy of Assistant Prof. Y. Kamada of Nagasaki University. This specimen was dredged from the bottom of this deep by the Soviet oceanographic expedition vessel "Vitiaz" and was given to Mr. Kamada by Dr. V. Kanajev, the chief geologist of this expedition party, when the party visited Nagasaki. This deep, $10,960 \mathrm{~m}$ in depth, found by this expedition is the deepest in the world, and is located at $11^{\circ} 16.6^{\prime} \mathrm{N}$. lat. and $142^{\circ} 09.9^{\prime} \mathrm{E}$. long., or about $3.2 \mathrm{~km}$ west of the Challenger deep, $10,860 \mathrm{~m}$ in depth in the Mariana trench, southwestern Pacific.

The submarine geology of this deep as explored by this expedition is as follows:

$$
\begin{array}{ll}
10,100 \mathrm{~m} & \text { diatomaceous ooze mud } \\
10,370 \mathrm{~m} & \text { mud } \\
10,910-10,930 \mathrm{~m} & \text { "basalt". }
\end{array}
$$

The specimen under discussion was dredged from a point about $10,700 \mathrm{~m}$ in depth on the western slope of this deep (see the index map).

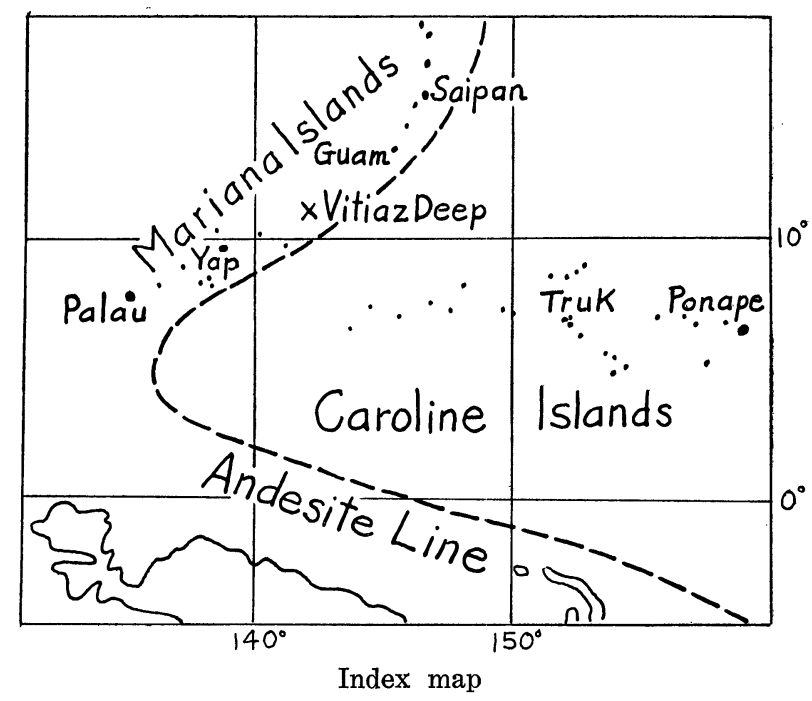

Petrographic description. It is a subangular and irregular shaped block, about $5 \mathrm{~cm}$ across, and has a fresh broken surface by which it 
was probably separated from the basement rock or a much larger block. It is bluish grey in color, and is fine-grained and compact. Specific gravity is 2.93. Under the microscope an ophitic texture is well developed, though sporadic phenocrysts of plagioclase are present. The constituent minerals are plagioclase, augite, magnetite, ilmenite, anorthoclase, cristobalite, and apatite in the order of abundance, with appreciable amount of glass. Olivine is entirely absent. Excepting partial serpentinization of glass, the rock is fresh and free from alteration. The modal composition (volume \%) is as shown in Table I.

Phenocrystic plagioclase, 1.0-2.5 $\mathrm{mm}$ in length, is always clear, and shows distinct zonal structure with calcic core surrounded by more sodic rim. For example, $A_{78}($ core $) \rightarrow A_{54}$ (margin). Average composition $\mathrm{An}_{66-61}$. Ophitic plagioclase is usually lath-

Table I. Modal composition (volume \%) of augite dolerite

\begin{tabular}{lr}
\hline Plagioclase & 49.0 \\
Augite & 30.0 \\
Iron ores & 4.5 \\
Anorthoclase & 0.7 \\
Cristobalite & 0.6 \\
Apatite & 0.4 \\
Glass & \\
$\quad$ fresh, with crystallites & 6.1 \\
Glass $\quad$ \\
$\quad$ serpentinized & 8.7 \\
\hline \multicolumn{1}{c}{ Total } & 100.0
\end{tabular}
shaped, less than $1.0 \mathrm{~mm}$ in length, and is also zoned: for example, $\mathrm{An}_{73}$ (core) $\rightarrow \mathrm{An}_{60} \rightarrow \mathrm{An}_{48} \rightarrow \mathrm{An}_{26}$ (margin). All plagioclases are of high form. Anorthoclase forms irregular fringes around plagioclase laths, or interstitial between them. $\alpha=1.531$. Cristobalite forms characteristic aggregates of scaly crystals in the interstices or vesicules. Apatite occurs in long needles.

Augite is always fresh, and shows a weak zonal structure, the color being slightly deeper in the margin than in the core. Pleochroism is very weak: $X^{\prime} \cdots$ slightly brownish with violet tinge, $Z^{\prime} \cdots$ slightly greenish. The augite is slightly titaniferous. Incomplete hour-glass structure is also observed.

$$
\begin{gathered}
\alpha=1.689, \quad \beta_{\text {mean }}=1.695, \quad \gamma=1.716, \\
b=Y, \quad c \wedge Z=41-43^{\circ}, \quad 2 V_{\text {mean }}=49^{\circ} . \\
\text { Chemical composition } \quad W_{41} E_{39} \mathrm{Fs}_{20} .
\end{gathered}
$$

Zonal structure: $2 \mathrm{~V} 53^{\circ}$ (core) $\rightarrow 49^{\circ} \rightarrow 44.5^{\circ}$ (margin). Rarely outermost thin rims or small isolated crystals of augite are pale green in color, suggesting they may be soda-augite. Titaniferous magnetite shows characteristic skeletal forms, less than $1.0 \mathrm{~mm}$ across. Rarely intergrowth of magnetite and augite is observed. Ilmenite forms slender prismatic crystals and is much less than magnetite in amount. In spite of well developed ophitic texture, abundant glass is present in the interstices. When fresh, it is pale brown with abundant minute crystallites, and on alteration, it is changed into brownish green serpentinous substance of low birefringence. Every stage of alteration is 
observed between the fresh glass and the altered one, and it is evident that the serpentinous substance is derivative not from olivine, but from glass.

The chemical composition and the norm of this augite dolerite are given in Table II. A high content of $\mathrm{CaO}$, and very low contents of alkalis, especially of $\mathrm{K}_{2} \mathrm{O}$, are worthy of note. It is evident that the rock belongs to the tholeiitic series, although its $\mathrm{TiO}_{2}$ content is rather high.

Table II. Chemical composition and norm of augite dolerite

\begin{tabular}{lrlr}
\hline $\mathrm{SiO}_{2}$ & 47.43 & $\mathrm{Q}$ & 1.32 \\
$\mathrm{TiO}_{2}$ & 2.51 & $\mathrm{Or}$ & 1.67 \\
$\mathrm{Al}_{2} \mathrm{O}_{3}$ & 13.63 & $\mathrm{Ab}$ & 23.06 \\
$\mathrm{Fe}_{2} \mathrm{O}_{3}$ & 5.69 & $\mathrm{An}$ & 24.19 \\
$\mathrm{FeO}$ & 7.27 & $\mathrm{Wo}$ & 12.41 \\
$\mathrm{MnO}$ & 0.15 & $\mathrm{En}$ & 17.00 \\
$\mathrm{MgO}$ & 6.81 & $\mathrm{Fs}$ & 4.75 \\
$\mathrm{CaO}$ & 11.04 & $\mathrm{Mt}$ & 8.35 \\
$\mathrm{Na} 2 \mathrm{O}$ & 2.71 & $\mathrm{Il}$ & 4.71 \\
$\mathrm{~K}_{2} \mathrm{O}$ & 0.31 & $\mathrm{Ap}$ & 0.34 \\
$\mathrm{H}_{2} \mathrm{O}+$ & 1.30 & & \\
$\mathrm{H}_{2} \mathrm{O}-$ & 1.19 & & \\
$\mathrm{P}_{2} \mathrm{O}_{5}$ & 0.14 & & \\
\hline Total & 100.18 & Analyst: & K. Yagi \\
\hline
\end{tabular}

Geologic significance. This dolerite is of some importance from the viewpoint of petrographic province. The volcanic rocks of the Mariana Islands are either tholeiitic rocks or calc-alkalic rocks derived from the former, while various kinds of alkalic rocks, including feldspathoidal rocks such as nepheline basalts or sodalite trachytes, are met with in the Caroline Islands: for example, Truk, Ponape, and Kusaie (Kaiser, 1903; Yosshii, 1936; Yagi, 1960). The so-called andesite line runs through between these two groups of islands, and makes the boundary between the two petrographic provinces of "circum-Pacific suites" and "intraPacific suites" (Macdonald, 1949).

The Vitiaz deep lies between Yap and Guam of the Mariana Islands, and to the west of this andesite line. As has been stated, the irregular and subangular shape of this specimen excludes the possibility that it is a pebble carried from some continental regions or some islands, but it is most likely that the specimen represents a part of the basement rock which constitutes the bottom of this deep. The similarity in petrographic character of this rock to some of the volcanic rocks, especially an augite pigeonite basalt (No. 41), dredged from the Jimmu seamount, northwestern Pacific, is worthy of mention. According to 
Kuno and co-workers, these volcanic rocks agree exactly with the volcanic rocks of the "circum-Pacific suite" (Kuno, Fisher, and Nasu, 1956). An occurrence of such an augite dolerite of tholeiitic series in the Vitiaz deep is in accordance with the interpretation on the petrographic provinces.

Acknowledgments. The writer wishes to express his sincere thanks to Dr. V. Kanajev and Mr. Y. Kamada for placing this valuable specimen at his disposal, to Prof. S. Tsuboi for critical reading of this paper in manuscript, and to Dr. K. Aoki and Mr. K. Uruno for their help in the laboratory.

\section{References}

Kaiser, E. (1903): Beiträge zur Petrographie und Geologie der Deutschen Südsee Inseln, Jb. König. Preus. Geol. Land. Berg., 24, 91-121.

Kuno, H., Fisher, R. L., and Nasu, N. (1956): Rock fragments and pebbles dredged near Jimmu seamount, northwestern Pacific, Deep-sea Res., 3, 126-133.

Macdonald, G. A. (1949): Hawaiian petrographic province, Bull. Geol. Soc. Amer., 60, 1541-1596.

Yagi, K. (1960): Petrochemistry of the alkalic rocks of the Ponape Island, western Pacific Ocean, Paper presented to XXI Intern. Geol. Congress.

Yosshii, M. (1936): Petrographic notes on the non-calcareous rocks from the South Sea Islands (in Jap.), Rept. Inst. Geol. Paleont. Tohoku Univ., 22, 1-50. 